\title{
Patient safety: analysis of the incidents notified in a hospital, in south of Brazil
}

\author{
Segurança do paciente: análise dos incidentes \\ notificados em um hospital do sul do Brasil \\ Seguridad del paciente: análisis del incidente \\ notificado en un hospital en el sur de Brasil
}

\author{
Elisiane Lorenzini ${ }^{\mathrm{a}}$ \\ Juliana Annita Ribeiro Santi ${ }^{b}$ \\ Ana Cristina Pretto Báoc
}

D0l: $\quad$ http://dx.doi.org/10.1590/1983-

1447.2014.02.44370

\footnotetext{
a Nurse, specialized in Management Nursing, Masters in Health Sciences. Post-Graduate in Nursing at the Universidade Federal do Rio Grande do Sul. Member of the study group in Nursing Management /NEGEUFRGS. Porto Alegre (RS), Brazil.

- Nurse, Faculdade Nossa Senhora de Fátima. Caxias do Sul (RS), Brasil.

c Nurse, Specialized in Risk Management and Hospital safety. Lecturer at the Nursing Department in Faculdade da Serra Gaúcha (FSG). Caxias do Sul (RS), Brazil.
}

\section{ABSTRACT}

This study aimed to evaluate the incidents reported between the years 2008 and 2012, in a large hospital in southern Brazil. This is a retrospective study of documentary analysis, transverse and descriptive with a quantitative approach. Data was collected in march 2013, analyzed and presented as absolute and relative frequency. We identified 755 cases; this represented $1.1 \%$ of total hospitalizations. The higher frequency of reporting in inpatient units was $64.8 \%$. The incident with the highest prevalence in this study was $45.4 \%$ falls, followed by medication error $16.7 \%$ and $16.2 \%$ other incidents. The low number of notifications can be related to the system adopted by the institution where the professional who notifies the incident needs to be identified.

Keywords: Patient safety. Medication errors. Accidental falls. Safety management.

\section{RESUMO}

Objetivou-se avaliar os incidentes notificados entre os anos 2008 e 2012, em um hospital de grande porte da região Sul do Brasil. Trata-se de um estudo retrospectivo de análise documental, transversal, descritivo, com abordagem quantitativa. Os dados foram coletados em março de 2013, analisados e apresentados em frequência absoluta e relativa. Identificaram-se 755 casos, que representaram 1,1\% do total de internações. A maior frequência de notificação ocorreu nas unidades de internação (64,8\%). 0 incidente de maior prevalência neste estudo foi a queda (45,4\%), seguida do erro de medicação (16,7\%) e outros incidentes (16,2\%). 0 baixo número de notificações pode estar relacionado ao sistema adotado pela instituição, onde o profissional que notifica o incidente precisa ser identificado.

Descritores: Segurança do paciente. Erros de medicação. Acidentes por quedas. Gerenciamento de segurança.

\section{RESUMEN}

El objetivo fue evaluar los incidentes reportados entre los años 2005 y 2012 en un gran hospital en el Sur de Brasil. Se trata de un estudio retrospectivo de análisis documental, transversal, descriptivo, con enfoque cuantitativo. Los datos fueron recolectados en marzo de 2013, analizados y presentados como frecuencia absoluta y relativa. Se identificaron 755 casos, estos representaron 1,1\% del total de hospitalizaciones. La mayor frecuencia de informes en las unidades de hospitalización fue del 64,8\%. El incidente de mayor prevalencia en este estudio fue la caída 45,4\%, seguida por error de medicación 16,7\% y 16,2\% de otros incidentes. El bajo número de notificaciones puede estar relacionado con el sistema adoptado pela institución, donde el profesional que notifica el incidente debe ser identificado.

Descriptores: Seguridad del paciente. Errores de medicación. Accidentes por caídas. Administración de la seguridad. 


\section{口INTRODUCTION}

The occurrence of incidents that compromise the safety of the patient has become a pressing challenge for all health service institutions. The incident may or may not involve injury. The injury incidents are called Adverse Events $(A E s)^{(1)}$. The patient safety issue has become more and more widespread within health institutions and amongst health professionals with respect to the constant search for the quality of care given and minimizing the number of avoidable incidents.

Everyday basic health care procedures are highly complex and despite the higher quality standards currently in place, AEs take place daily. Worldwide there are between $2.9 \%$ and $16.6 \%$ of inpatients affected by AEs, such as complications during or post-operation, medication errors, health care associated infections (HAl) or patients falling from their beds ${ }^{(2-3)}$.

The publication of the study The Error is Human in 1999 by the Institute of Medicine (IOM) showed that between approx. 44,000 to a 98,000 people died every year in American hospitals, victims of $A E s^{(4)}$. The occurrence of AEs is a significant worldwide issue and it also represents huge financial loss.

In response to this global necessity, WHO, launched in 2004, The World Alliance for Patient Safety. The programme has strategies, guidelines and international targets which aim to disseminate and ensure practices that enable the safety of patients in different countries ${ }^{(5)}$. The Alliance acts in different areas, from hand washing, safe surgery to taxonomy which aims to organize taxonomical aspects pertaining to the theme of patient safety ${ }^{(6)}$.

In Brazil there are more than 200 thousand healthcare establishments in place where sick people are routinely treated using health technologies and with the assistance of health professionals, and therefore are subject to $\mathrm{AEs}^{(7)}$. A study undertaken in three university hospitals in the State of Rio de Janeiro showed that $7.6 \%$ of the total of 1,103 inpatients in 2003 suffered from AEs and of these 66.7\% could have been avoided ${ }^{(8)}$. These findings suggest that possible problems regarding patient safety are more frequent in Brazilian hospitals than in developed countries( ${ }^{(8)}$.

This comparative encouraged, in the last decade, the promotion of different initiatives to provide safer healthcare. Among these initiatives, stands out the creation of indicator-based programmes for the monitoring the quality and safety. In April 2013, a National Programme for Patient Safety was created in Brazil, with the view, amongst other objectives, to monitoring and the prevention of damage in healthcare ${ }^{(9)}$. Taking into consideration the lack of available data which makes it difficult to define accurately the magnitude of the problem of AEs in Brazil, the current study is justified because it allows for the possibility of an increased understanding of this internationally discussed theme, patient safety. The measurement of data provides figures for formulating plans and strategies with the objective of significant improvement in patient safety. Hence, the key question of this study is put forward: What are the incidents which occur during the provision of healthcare in a large hospital? Therefore, the objective of this study is to assess the recorded incidents between 2008 and 2012, in a large hospital situated in the South of Brazil.

\section{DETHOD}

It is a retrospective documental analysis, transversal and descriptive study with a quantitative approach.

This study was developed in a large institution, with a philanthropic character, which attends to the users of SUS - Unified Health System and Supplementary Heath Agency situated in the South of Brazil. No exclusion criteria were considered, so all notified incident records were included and analysed for the period between 2008 and 2012. Data collection was carried out in March 2013, by the researcher, through the electronic records of the incidents notified in the institution. This data was collected in a regular way and digitized into a Microsoft Office Excel 7 spreadsheet. Another identical spreadsheet was produced by the researcher.

For the statistical analysis we considered the following variables: data, incident, place of occurrence department, age and gender. The Statistical Package for Social Sciences programme (SPSS) 17.0 version was used. All the categorized data was presented in absolute and relative frequency.

The research complied with the guidelines of Resolution 196/96 $6^{(10)}$ of the National Council for Health; it was authorized by the institution where the research took place and approved by the Ethics Committee in the Virvi Ramos Research with the protocol number 224.450 and CAAE 12266513.7.0000.5523.

\section{RESULTS}

In this study we analysed 755 notified cases of incidents between 2008 and 2012. According to results obtained, the year of 2008 presented the smallest percentage of notified cases - 103 (13.6\%), while 2012 was the year with the highest percentage 239 (31.7\%), as shown in Figure 1.

The increase in the total number of incidents notified shown as an annual comparison is - from 2008 to 2009, 


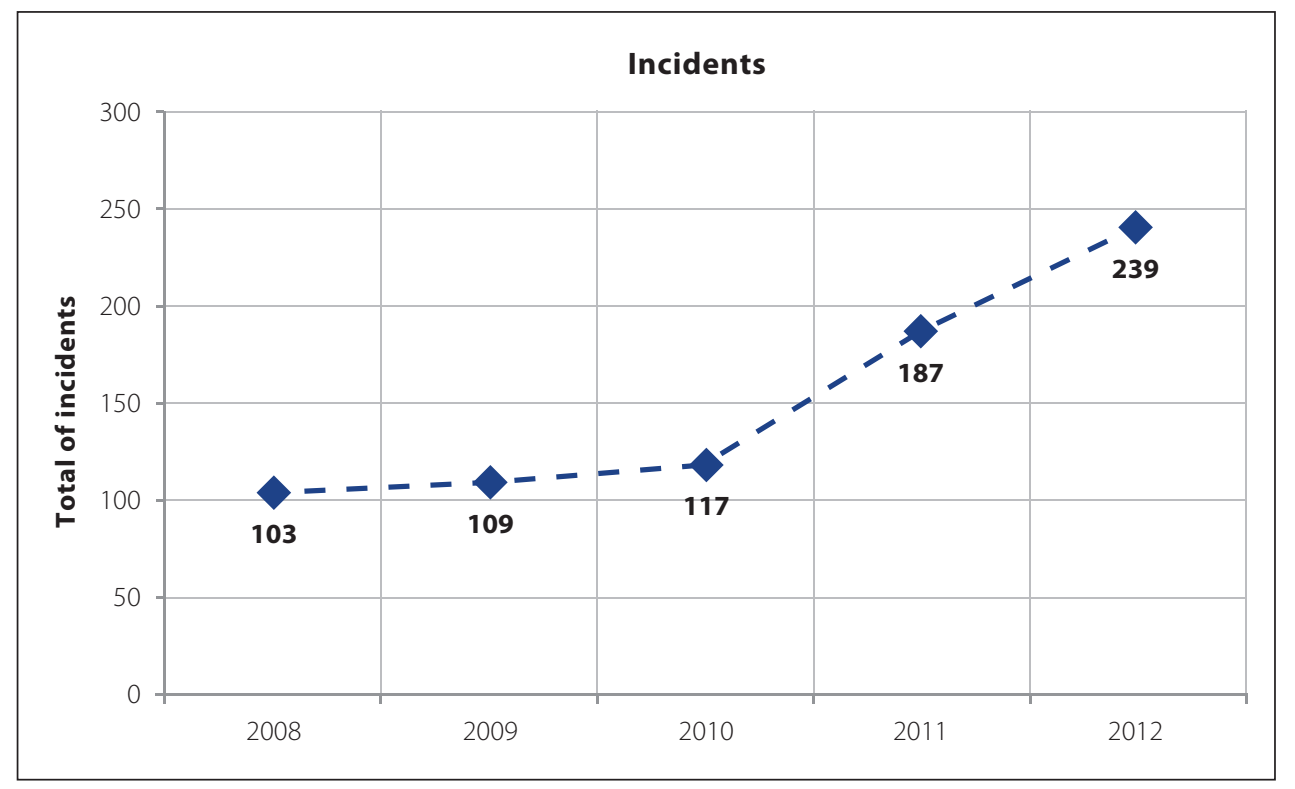

Figure 1. Absolute distribution of the incidents notified between 2008 and 2012. Caxias do Sul, RS, 2012.

Source: Research data

the increase was 5.8\%; from 2009 to 2010 the increase was 7.3\%; from 2010 to 2011 - 59.8\% and from 2011 to 2012 the proportional increase of cases was $27.8 \%$. Therefore the data shows a proportional average increase between 2008 and 2012 of $25.2 \%$.

Taking as a base the quantitative admissions for each year, there were a total of 71,037 admissions. Carrying out the weighting of the number of incidents notified against the number of admissions, we found that actually the increase was 142\% of the incidents in 2008 (0.7\%) compared to $(1.7 \%)$ in 2012. Regarding the total of incidents these represent $1.1 \%$ of the total admissions.

As to the place of occurrence shown in Table 1, the incidents were more frequent in the internship units; 487 (64.8\%).

The diverse types of incidents with medical products, Table 2, represent 151 (20\%). The incidence of highest prevalence observed in this study was for falls $343(45.4 \%)$ of cases, Table 3, followed by medication errors 126 (16.7\%) of the total incidents and other events 123 (16.2\%) as shown in Table 2.

When analysing the incidents notified regarding gender, Table 4, we observed that for the total amount of incidents notified, there was no significant difference in the distribution between men 377 ( 50.4\%) and women 372 (49.6\%).

With regards to age, Table 4 , for the total amount of incidents the ages from 13 to 59 years old predominate 377 (51.8\%) and from 60 years or more 303 (41.6\%) of incidents notified.

\section{DEBATE}

The results of this study show that the occurrence of incidents notified were $1.1 \%$ of the total admissions, less than what was found in another Brazilian study of $1.47 \%$ (11). Another more recent research made in three Brazilian school hospitals in Rio de Janeiro identified a $7.6 \%$ incidence of patients suffering from AEs, although only $66.7 \%$ of them were considered avoidable ${ }^{(12)}$.

The international method most used to detect incidents and AEs is voluntary notification. However, this method contains some limitations, sub notification due to time limits, lack of appropriate information system, fear of litigation, reluctance of people to confront their own mistakes, lack of understanding of the importance of the event and a lack of action after notification. However this method of communication is the most useful for the induction of behaviour changes, showing the benefits of the production of AE's records, because it allows us to learn from our own mistakes. The presence of a voluntary safety team which is multidisciplinary can help to elaborate on the reports( ${ }^{(6)}$.

The results of this study shows a considerable increase in the number of incidents notified 103 (13.6\%) in 2008, against 239 (31.7\%) in 2012. It is important t highlight that the institution that provided the data for this study, has been developing its safety policies, firstly by joining the Hospital Accreditation System and secondly by the promotion of the campaign for safety of patients in 2010. 
Table 1. Absolute and relative distribution of the incidents notified occurred in each department against the total of incidents analysed per year. Caxias do Sul, RS, 2012.

\begin{tabular}{lcccccc}
\multicolumn{1}{c}{$\begin{array}{c}\text { Departments } \\
(\mathbf{A D = 3}(\mathbf{0 , 4} \mathbf{4}) \mathbf{)}\end{array}$} & Total* & \multicolumn{5}{c}{ Year $^{\mathbf{t}}$} \\
\cline { 3 - 7 } & & $\mathbf{2 0 0 8}$ & $\mathbf{2 0 0 9}$ & $\mathbf{2 0 1 0}$ & $\mathbf{2 0 1 1}$ & $\mathbf{2 0 1 2}$ \\
\hline Internship Unit & $487(64.8)$ & $91(18.7)$ & $90(18.5)$ & $75(15.4)$ & $115(23.6)$ & $116(23.8)$ \\
Intensive and Intensive Care Unit & $50(6.6)$ & $4(8.0)$ & $2(4.0)$ & $4(8.0)$ & $16(32.0)$ & $24(48.0)$ \\
Neonatal Intensive Care Unit & $26(3.5)$ & & $1(3.8)$ & $3(11.5)$ & $4(15.4)$ & $18(69.2)$ \\
Emergency Room & $27(3.6)$ & $1(3.7)$ & $5(18.5)$ & $4(14.8)$ & $5(18.5)$ & $12(44.4)$ \\
Emergency Care Unit & $8(1.1)$ & $3(37.5)$ & $3(37.5)$ & & $2(25.0)$ & \\
Operating Room & $35(4.7)$ & $1(2.9)$ & $2(5.7)$ & $7(20.0)$ & $11(31.4)$ & $14(40.0)$ \\
Recovery Room & $11(1.5)$ & & & $4(36.4)$ & $5(45.5)$ & $2(18.2)$ \\
Obstetrics Centre & $12(1.6)$ & & $1(8.3)$ & $1(8.3)$ & $1(8.3)$ & $9(75.0)$ \\
Nephrology Institute & $14(1.9)$ & $1(7.1)$ & & $2(14.3)$ & $5(35.7)$ & $6(42.9)$ \\
Cancerology Institute & $40(5.3)$ & & & $10(25.0)$ & $17(42.5)$ & $13(32.5)$ \\
Sector 230 & $30(4.0)$ & $1(3.3)$ & $1(3.3)$ & $4(13.3)$ & $4(13.3)$ & $20(66.7)$ \\
Others & $12(1.5)$ & $1(8.3)$ & $2(16.3)$ & $3(25.0)$ & $2(16.3)$ & $2(16.3)$ \\
\hline
\end{tabular}

Source: Research data.

Key words: AD: Absent Data 3 (0.4\%); Others: X-Ray room, Laboratory, Diagnostic Imaging Department, Nursery, Outpatient Care.

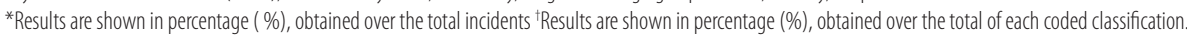

Table 2. Absolute and relative distribution of the medical product related incidents notified against the total of medical product related incidents analysed per year. Caxias do Sul, RS, 2012.

\begin{tabular}{lcccccc} 
& \multirow{2}{*}{ Medication-related incidents } & Total* & \multicolumn{5}{c}{ Years $^{\dagger}$} \\
\cline { 3 - 6 } & & $\mathbf{2 0 0 8}$ & $\mathbf{2 0 0 9}$ & $\mathbf{2 0 1 0}$ & $\mathbf{2 0 1 1}$ & $\mathbf{2 0 1 2}$ \\
\hline Drug administration using wrong method & $8(3.1)$ & & $1(12.5)$ & & $4(50.0)$ & $3(37.5)$ \\
Drug administration at the wrong time & $9(3.4)$ & & & $1(11.1)$ & $3(33.3)$ & $5(55.6)$ \\
Chemotherapy Spillage & $16(6.1)$ & & & & $2(12.5)$ & $14(85.7)$ \\
Wrong medication & $10(3.8)$ & & & $2(20.0)$ & $3(30.0)$ & $5(50.0)$ \\
Deteriorated medication & $5(1.9)$ & $1(20.0)$ & & & $3(60.0)$ & $1(20.0)$ \\
Medication wrongly administrated & $29(11.1)$ & & & $6(20.7)$ & $12(41.4)$ & $11(37.9)$ \\
Wrong dosage & $126(48.3)$ & $7(5.6)$ & $18(14.3)$ & $20(15.9)$ & $39(31.0)$ & $42(33.3)$ \\
Wrong medication & $35(13.4)$ & $1(2.9)$ & & $10(28.6)$ & $10(28.6)$ & $14(40.0)$ \\
Omission mistake & $2(0.8)$ & & & & $2(100.0)$ & \\
Prescription mistake & $21(8.0)$ & & & & $7(33.3)$ & $14(66.7)$ \\
Chemotherapy overflow & & & & &
\end{tabular}

Source: Research data.

* Results are shown in percentage (\%), obtained over the total incidents. 'Results are shown in percentage (\%), obtained over the total of each classification of event.

Even though there was an increase in the total number of notifications yearly, the numbers found are still very low, which suggests that the notification system adopted by the institution - where the professional who notifies the incident must identify them self - can greatly help increase the number of sub notification.

In general, although there is an obvious increase in the number of incidents notified, national and international 
Table 3. Absolute and relative distribution of the incidents notified against the total of incidents analysed per year. Caxias do Sul, RS, 2012.

\begin{tabular}{lcccccc} 
& \multirow{2}{*}{ Incidents } & Total* & \multicolumn{5}{c}{ Year $^{\dagger}$} \\
\cline { 5 - 7 } & & $\mathbf{2 0 0 8}$ & $\mathbf{2 0 0 9}$ & $\mathbf{2 0 1 0}$ & $\mathbf{2 0 1 1}$ & $\mathbf{2 0 1 2}$ \\
\hline Cross breast-feeding & $14(1.9)$ & & & $1(7.1)$ & $1(7.1)$ & $12(85.7)$ \\
Others & $\mathbf{1 2 3 ( 1 6 . 2 )}$ & $\mathbf{8 ( 6 . 7 )}$ & $\mathbf{9 ( 7 . 5 )}$ & $\mathbf{2 1 ( 1 6 . 7 )}$ & $\mathbf{3 7}(\mathbf{3 0 . 0 )}$ & $\mathbf{4 8 ( 3 9 . 4 )}$ \\
Access loss & $14(1.9)$ & & & & $3(21.4)$ & $11(78.6)$ \\
Falls & $343(45.4)$ & $86(25.1)$ & $81(23.6)$ & $56(16.3)$ & $61(17.8)$ & $59(17.2)$ \\
\hline
\end{tabular}

Source: Research data.

Key words: Others (Catheter obstruction. Accidental extubation. Faulty preparation. Wrong log entry. Escape, etc...)

* Results are shown in percentage (\%), obtained over the total incidents. 'Results are shown in percentage (\%), obtained over the total of each classification of event.

Tabela 4. Absolute and relative distribution of notified incidents for gender and age, for total incidents and for the year evaluated. Caxias do Sul, RS, 2012.

\begin{tabular}{lcccccc}
\multirow{2}{*}{$\begin{array}{l}\text { Variables } \\
\text { Gender AD=6 (0,8\%) }\end{array}$} & Total* & \multicolumn{5}{c}{ Years $^{\dagger}$} \\
\cline { 3 - 6 } & & $\mathbf{2 0 0 8}$ & $\mathbf{2 0 0 9}$ & $\mathbf{2 0 1 0}$ & $\mathbf{2 0 1 1}$ & $\mathbf{2 0 1 2}$ \\
\hline Females & $372(49.6)$ & $49(13,2)$ & $42(11.3)$ & $50(13.4)$ & $91(24.5)$ & $140(37.6)$ \\
\hline Males & $377(50.4)$ & $54(14.3)$ & $66(17.5)$ & $67(17.8)$ & $94(24.9)$ & $96(25.5)$ \\
\hline Age group AD=27 (3,6\%) & & & & & \\
\hline Less than 1 year & $34(4.7)$ & $0(0.0)$ & $2(5.9)$ & $5(14.7)$ & $2(5.9)$ & $25(73.5)$ \\
\hline From 1 to 12 & $14(1.9)$ & $1(7.1)$ & $0(0.0)$ & $3(21.4)$ & $5(35.7)$ & $5(35.7)$ \\
\hline From 13 to 59 & $377(51.8)$ & $60(15.9)$ & $59(15.6)$ & $52(13.8)$ & $93(24.7)$ & $113(30.0)$ \\
\hline 60 and over & $303(41.6)$ & $42(13.9)$ & $47(15.5)$ & $50(16.5)$ & $78(25.7)$ & $86(28.4)$ \\
\hline
\end{tabular}

Source: Research data.

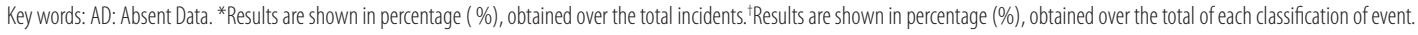

studies show that fear and concern are still present in situations of wrong-doing with or without sub notification ${ }^{(2,6)}$. Despite all the campaigns and incentives from WHO for notification of mistakes, aiming towards a process of analysis of those situations, so allowing action plans to be created to prevent new occurrences, In Brazil, unfortunately, a culture of professional punishment still prevails ${ }^{(2)}$. The lack of understanding of what is considered wrong-doing and possible irregularities in dealing with the patient and fear regarding their professional future are factors which make workers not report any kind of error caused or related to the patient $\mathrm{t}^{(13)}$.

In this study, the place where the most frequently reported occurrence of incidents took place was in the Internship Units 487 (64,8\%), which can be related to the higher number of beds and inpatients in these units. In second place, with regard to frequency of occurrences, were the Intensive Treatment Units and Intensive Care Units for adults 50 (6.6\%). An assessment study on AEs in three public school hospitals in the State of Rio de Janeiro, Brazil, revealed that AEs are most often found $-36.2 \%$ of the total cases - in surgical procedures. The operating room was the second place with higher frequency of AEs $34.7 \%$ of the cases $^{(8)}$.

With regards to wrong medication errors (ME) a rate of 126 (16.7\%) of the total incidents was found, making it the second most frequent in this study. In other research, the findings were, however, that the medication errors (ME) were $62.7 \%$. Understanding the types of errors which prevail in a hospital and the system of sub layers involved is paramount for the improvement of drug administration in that hospital. However we should highlight that there 
is evidence that shows that professionals do not know all medication errors, which leads to a lower notification ${ }^{(14)}$.

Some literature shows that ME can occur at any stage of medical therapy, it represents approximately $65 \%$ of all the $\mathrm{AES}^{(15)}$. In this investigation, the most frequent ones were medication errors, omission errors, dosage errors, drug administration at the wrong time and drug administration using the wrong method. This indicates that these mistakes don't constitute, eminently, mistakes performed by the professionals, on the contrary, they can also be a result of the medication chain as a whole.

A study done in Spain shows that ME has a rate of $5.21 \%$, revealing it to be one of the most frequent incident types ${ }^{(16)}$. Another study undertaken in five Brazilian university hospitals reveals that one of the main causes for ME is drug administration using methods different to those prescribed with 92 (6.5\%) of the total of 1,425 MEs. These mistakes were assigned to items listed in the medical prescription, such as codes or abbreviations in the dosage list, and also occurred when the prescription was in an electronic form.

A study of invasive monitoring of the use of antimicrobial agents in a hospital in Parana identified the occurrence of $91 \mathrm{AEs}$, however 3.3\% were adverse reaction to the medication and $7.7 \%$ were mistakes in the notification. In a university hospital in Ribeirão Preto, in the state of São Paulo, 925 prescriptions were analysed, 21\% of them had erasures and $28.2 \%$ had unclear information on them ${ }^{(14)}$. The researched literature assigned low scientific technical knowledge and a lack of updating in the nursing staff as one of the main causes of $\mathrm{ME}^{(13)}$.

It should be pointed out that the relationship between the subject and the organization where they work can have a negative effect on the health carers performance, and this can contribute to the occurrence of incidents and AEs. Some factors such as high numbers of patients, high levels of noise and light and long working hours can also contribute to AE numbers, as well as changing shifts and the occurrence of conflicts ${ }^{(17)}$.

Among the main incidents which could be prevented in health institutions, falls, represented the incident with the greatest occurrence in this study 343 (45.4\%). For elderly inpatients or patients with home carers, falls are one of the most common sources of injury, causing skin trauma, fractures and also death ${ }^{(18)}$.

Constant patient surveillance is an important factor in preventing falls. There is also evidence that an appropriate number of infirmary nursing staff helps obtain better results in care and, consequently, a reduction in the rate of falls of hospitalized patients ${ }^{(19)}$. A study in a tertiary hospital, in the South of Brazil, revealed that increasing patient numbers for a nursing team over $24 \mathrm{hrs}$, elevated the incidence of falls from beds among the attended patients ${ }^{(3)}$.

Cross breast-feeding was present in 14 (1.9\%) of the cases. It is considered an old practice, but is still around today, and is breast feeding of a newly born baby by another mother to help in weight gain or comfort of the recently born. Cross breast feeding can be offered by mothers of interned babies or by professionals who have children at this period ${ }^{(20)}$. It is know that cross breast feeding can cause diseases which could harm the baby. With regards to risk management and patient safety, this type of incident is considered avoidable. Records of these incidents are paramount for the implementation of strategies to avoid reoccurrence. The intervention of nurses holds a central role in directing the infirmary team and breast feeding mothers, so promoting health education.

When analysing the incidents notified in relation to gender, we observed that there was no significant difference between men 377 (50.4\%) and women 372 (49.6\%), confirming the Spanish study that didn't find any significant difference between the genders ${ }^{(16)}$.

In this study notified incidents predominated in the age group from 13 to 59 years 377 (51.8\%), while patients over 60 years old were 303 (41.6\%) of the notified incidents. These statistics don't match with the data found in other research where incidents predominated in patients of more than 62 years old ${ }^{(16)}$.

\section{CONCLUSION}

From the total of 755 incidents notified between 2008 and 2012, we observed an increase of 142\% in 2008 incidents (0.7\%) compared to 2012 (1.7\%). The prevalence was $1.1 \%$ over the total number of admissions, falls being $45.4 \%$ and errors with medication $16.7 \%$ of the total number of incidents notified. A low number of notifications might be due to the system adopted by the institution, where, the professional reporting the incident must be identified.

This study contributes in widening the understanding of this much discussed worldwide theme, Safety of the Patient. Through an analysis of notified incidents, it is suggested that health institutions work towards a culture of safety, considering as a starting point, the planning of actions to promote the safety of the patient. To achieve this, it is necessary that all are involved, from managerial staff through to staff at all the various operational levels.

Absent data created limitations to this study however we don't consider that the results obtained and presented were compromised. It is important to highlight that this 
study was undertaken in one institution only, so does not guarantee a generalization of results. For this reason, we suggest that other studies are made, with different methods, in different institutions, so that new strategies can be drawn up to help avoid the occurrence of incidents and advert events.

\section{REFERENCES}

1. Runciman W, Hibbert P, Thomson R, Van Der SchaafT, Sherman H, Lewalle P. Towards an international classification for patient safety: key concepts and terms. Int J Qual Health Care. 2009;21(1):18-26.

2. Silva EF, de Faveri F, Lorenzini E. Errores de medicación en el ejercicio de la enfermaría: la revisión integrativa. Enfermería Global. 2014;13(34):330-7.

3. Magalhães AMM, Dall'Agnol CM, Marck PB. Carga de trabalho da equipe de enfermagem e segurança do paciente: estudo com método misto na abordagem ecológica restaurativa. Rev Latino-Am Enfermagem. 2013;21(nesp):146-54.

4. Kohn LT, Corrigan JM, Donaldson MS, editors. To err is human: building a safer health system. Washington: The National Academy Press; 2000.

5. World Health Organization. World alliance for patient safety. [mentioned in 15 aug. 2012] Available in: http://www.who.int/patientsafety/worldalliance/en/.

6. Garrouste-Orgeas M, Philippart F, Bruel C, Max A, Lau N, Misset B. Overview of medical errors and adverse events. Ann. Intensive Care. 2012 Feb 16;2(1):2.

7. Agência Nacional de Vigilância Sanitária (BR). Assistência segura: uma reflexão teórica aplicada à prática. Brasília; 2013. Available in: http://www.anvisa.gov. br/hotsite/segurancadopaciente/documentos/junho/Modulo\%201\%20-\%20 Assistencia\%20Segura.pdf

8. Mendes W, Martins M, Rozenfeld S, Travassos C. The assessment of adverse events in Brazilian hospitals. Int J Qual Health Care. 2009;21(4):279-84.

9. Ministério da Saúde (BR). Portaria nº 529, de $1^{0}$ de abril de 2013. Institui o Programa Nacional de Segurança do Paciente (PNSP) [citado em 11 fev. 2014]. Bra-

\section{Author's address:}

Elisiane Lorenzini

Rua Felipe dos Santos, 77/201 A, Padre Reus

93020-180, São Leopoldo, RS

E-mail: elisilorenzini@gmail.com sília (DF). Available in: http://bvsms.saude.gov.br/bvs/saudelegis/gm/2013/ prt0529_01_04_2013.html.

10. Ministério da Saúde (BR). Conselho Nacional de Saúde. Resolução n. 196/96. Dispõe sobre diretrizes e normas regulamentadoras de pesquisa com seres humanos. Brasília (DF); 1996

11. Paiva MC et al. Caracterização das quedas de pacientes segundo notificação em boletins de eventos adversos. Rev Esc Enferm USP. 2009;44(1):134-8.

12. Gouvêa CSD, Travassos C. Indicadores de segurança do paciente para hospitais de pacientes agudos: revisão sistemática. Cad Saúde Pública. 2010;26(6):1061-78.

13. Telles PC, Praxedes MF, Pinheiro ML. Erros de medicação: análise do conhecimento da equipe de enfermagem de uma instituição hospitalar. Rev Gaúcha Enferm. 2011;32(3):539-45.

14. Camerini GF, Silva DL. Segurança do paciente: análise do preparo de medicação intravenosa em hospital da rede sentinela. Texto Contexto Enferm. 2011;20(1):41-9.

15. Gimenes FR. Administração de medicamentos, em vias diferentes das prescritas, relacionada à prescrição médica. Rev Latino-Am Enfermagem. 2011;19(1):7 telas.

16. Merino P, Álvarez J, Martín MC, Alonso, Gutiérrez S. Adverse events in Spanish intensive care units: the SYREC study. Int I Qual Health Care. 2011;24 (2):105-13.

17. Azoulay E, Timsit JF, Sprung CL, Soares M, Rusinova K, Lafabrie A, et al. Prevalence and factors of intensive care unit conflicts: the conflicts study. Am J Respir Crit Care Med. 2009;180(9):853-60.

18. Tinetti ME, Baker DI, King M, Gottschalk M, Murphy TE, Acampora D, et al. Effect of dissemination of evidence in reducing injures from falls. N Engl J Med. 2008;359(3):252-61.

19. Lorenzini E, Deckman LR, Costa TC, Silva EF. Dimensionamento de pessoal de enfermagem: revisão integrativa. Cienc Cuid Saúde. 2014;13(1):166-71.

20. Pedron CD, Bonilha ALL. Práticas de atendimento do neonato na implantação de uma unidade neonatal em hospital universitário. Rev Gaúcha Enferm. 2008;29(4):612-8.
Received: 27.12.2013

Approved: 09.05.2014 